\title{
Socio Economic Conditions of Urban Slum Dwellers in Kannur Municipality
}

\author{
Sufaira.C \\ Research scholar, Department of Economics, Central University of Kerala, Kasaragod, Kerala, India
}

\begin{abstract}
Improving quality of life in the slum is one of the development goals for new millennium. The existence of slums is essentially a manifestation of poverty, along with the economic and industrial development-slums will continue to exist and grow further. The experience of Kerala shows that the condition of the people can be improved even at low levels of economic development through appropriate public action for social provisioning and redistribution. Kerala has been able to provide for the basic needs of most of its citizen. This is revealed by comparative indicators of health, education and demographic transition. These average indicators hide the experience of communities that have been left out of the development process such as the fisher folk and the tribal's. Increasing numbers of slums constitute a major challenge to development.The result emphasizes the need for measures to improve the physical environment of the dwelling places like basic amenities of toilets, proper drainage, sewerage system and adequate water supply.
\end{abstract}

\section{Introduction}

The sprouting of slums in the urban areas is the direct outcome of greater economic opportunities available in the cities and towns. The demonstration effect of improved standard of living prevailing in the urban area has also attracted not only the population from smaller settlements, but also the rural migrants to almost all the major urban centers resulting in the emergence of slums even in the heart of the cities. These slums occurred due to various factors, namely the shortage of developed land being beyond the reach of urban poor; large influx of population, rural migration to cities in search of jobs and inadequate provision of basic services and infrastructural facilities in the urban areas. In general, slums are the products of failed policies, bad governance, corruption, inappropriate regulation, dysfunctional land markets, unresponsive financial systems and a fundamental lack of political will ${ }^{2}$.

Kerala has achieved outstanding progress in Human Development, which was reflected in the high level of education and health of its population. Crude Death Rate, Infant Mortality Rate and Life Expectancy at birth in Kerala are comparable even to those in the developed countries (World Bank, 1993). Notwithstanding the advanced level of Kerala, the question arises that whether the fruits of human development were fairly shared by all segment of population. Studies held in this regard revealed that all section of population have not benefited fully out of the development process ${ }^{3}$. Among the urban population, slum dwellers were the poorest. Literacy and education were the hall mark of Kerala Social Development. On this count also, slum population lag behind. They have remained poor, deprived of the basic nutrition, rudimentary shelter, minimally competent medical attention and basic education posing a great challenge to Kerala model of development.The main objective of the present study is to analyze the socio-economic conditions of theslum dwellers in Kannur District.

\section{Review Of Literature}

Several studies have examined various aspects of slums and come out with diverse findings. While some studies have concluded the impact of the government Programmes to be ineffective or moderate in reducing growth of slums, k (Hussain A, karat SM and Kavle, 1999) others indicate that socio economic condition of the slums are worse (Ali AM and Joran K, 2003) and yet others suggests that the utilization of health services are inefficient (Jatindar, 1999). Here we have made an attempt to review some important socio economic aspects of slums in the world.

Akter T (2008) highlights the socio economic condition of slum dwellers and their consumption pattern .The field data of the present study analyze the living conditions, Physical Environment, household's health

\footnotetext{
${ }^{1}$.Isaac and Tharakan, 2004.

2 .Gurumukhi K.T ,2000

${ }^{3}$ Gangadharan K ,2005
} 
behavior particularly dietary practice and health outcomes in Dhaka city.On the basis of access to food and utilization of food, living conditions and the situation of food security of urban poor were analyzed. The study observed that living condition of slum dwellers was considerably poor. Socio-economic status of slum dwellers can be characterized as mainly low income group with inadequate education, also poor physical environment with non-existent solid waste disposal system was very common phenomenon in slum areas. Therefore high prevalence of disease among children's living in slums indicates leading unhealthy environment. In such circumstances to ensure food security of urban poor is a challenge if their socio economic condition remains bleak. The study shows that high prevalence of disease among children's reveals inadequate education or lack of consciousness among parents to give proper care to the children. The study found that majority of them can't afford nutritious food which was expensive to them, socio economic factors like income, expenditure and education were influencing food security in slums were also found.

Asker R, Aslam K.S and Akthar M (1992) points out that socio economic condition of the migrants in slums of Faisabad city. The studies observed that living condition of the slum dwellers were poor. The facilities for proper disposal of garbage were limited. The study revealed that about $46 \%$ of rural migrants were unskilled and $18 \%$ were unskilled workers. Lack of lavatories forced the slum dwellers to use the open space around. This tended to create a serious problem of sanitation. The study empirically proved that socio economic factors affecting living conditions of rural migrants.

Ali AM and Toran K (2003) analysed about inter and intra migration and also the socio economic strata of the slum dwellers of Gandhi agar Slum. Most of the slum dwellers have migrated from the southern part of the city. On the basis of income and expenditure, socio economic conditions of the people were not good. Houses were well built concrete structures. Basic amenities, drainage, water supply, street lighting was good. But they face the problem of lack of library. The studies showed that majority of the migrants have come to this particular area because of cheap accommodation. Most of the slum dwellers have an active after work life, being regular outdoor recreational spots and making frequent visits to relatives.

Based on NSSO and Census data Chandrasekhar S (2005) gives a picture of difference in the conditions of slums in India and compared the conditions prevailing in the non slum urban, rural areas and the slums. On the basis of census report shows that there is a decline in the person's lived in the slums. The study showed that literacy rate in rural areas is higher than the slums in states like Kerala, Goa, and Delhi. But the poorer states like Bihar, Madhyapradesh, Rajasthan, literacy rate in slums was higher than rural areas. in the case of sex ratio, slums is higher than in rural areas. In rural areas availability of electricity is higher than slums. The study reveals that for every monthly percapita consumption expenditure class, the percentage of rural household without access electricity, latrines and water facilities was higher than corresponding households in slums and non-slum urban areas. Thus the study found that slums are similar to rural areas in some aspects and dissimilar in some other aspects.

Geetha S and SwaminathanMadhura (1996) in a field study in the slum area of Mumbai revealed that absence of basic civic amenities such as safe and adequate water supply, sewerage and sanitation, toilets are the root cause of many diseases leading to udernutrition in slum areas. The sex wise nutritional status, children aged five and below showed that girls have higher prevalence of under nutrition compared to boys. In this study weight for age and Midarm circumference indicators were used. On the basis of weight for age, $60.9 \%$ of boys and $72 \%$ of girls were undernourished. The MAC indicator showed that $19.8 \%$ of boys and $36.8 \%$ of girls were undernourished and another $25.2 \%$ of boys and $33.1 \%$ of girl's were moderately undernourished. Both the indicators show that the incidence of under nutrition was significantly higher among girls than boys.

HatekarNeeraj and Rode Sanjay (2003) observed that there were socio cultural and behavioral barriers like female illiteracy, poor economic status of women etc which affect the nutritional status of children. On the basis of nutritional indicators the study showed that severe malnourishment was found to be higher in Mumbai than in Jawaharlal colony. The study showed that seasonal wasting incidence is likely to be higher in girls. Malnourishment is very likely to occur when insufficient incomes co-exist with poor coverage of basic amenities and health services. Girls in urban areas tend to better than those in rural areas. But at the same time urban slum dwellers are undernourished. Proportion of undernourishment was very high in slum areas. The study empirically proved that the incidence of malnourishment among urban slum children was very close to the incidence of jawahar tribal.

Karn S.K, Shigeo Shikura and Harada Hideki (2003) examined the relationship between living environment and Health Status of Urban communities in Mumbai. The survey covered 1070 households in slums, squatters and Pavement dwellers. The study showed that education level and location of residence have influence on the employment type. Housing conditions differ considerably from pavement dwellers to squatters and slums, overall $33 \%$ houses were flimsy, $39 \%$ semi-permanent type and $28 \%$ cemented buildings. In slums, none of the household use any kind of scientific devices for pathogen killing or germs filteration.Polluted drinking water, insanitary living conditions, poor personal hygiene and food cleanliness are contributed to water related diseases. The impact of poverty and environmental factors highly pronounced between slums and 
pavement Dwellers. The study revealed that income, literacy, sanitation and personal hygiene have had impact on the morbidity of the people. The study empirically proved the effect of socio-economic and the environmental factors affecting health status of urban poor.

Gangadharan K (2005)studied the health behavior of five social classes, upper class, upper middle, lower middle, upper lower, lower in the utilization of health services in Kannur district. The prevalence rate of illness was high among children below 15 and those exceed 55 both in the slum and urban areas. Those in the age group of 36 to 55 also accounted for high morbidity both in the slum and urban areas. The study revealed that morbidity prevalence was inversely related to education and household size. The linkage of morbidity and occupation reveals that among employed group's unskilled workers accounts for higher morbidity of infectious illness, whereas chronic disease is dominated among business class and white collar workers. Among the unemployed groups also the morbidity of chronic illness was high both in the slum and urban areas were also found. The study of age and system of medicine utilized revealed that at the age up to 15 and at the age above 60 allopathy was utilized maximum both in the urban and slum areas. The study proved that with an increase in the level of education, utilization of private health facilities goes up and the utilization of public health facilities comes down. The study observed that both the urban and slum area very low social class households were educationally backward, their knowledge, level of diseases, available health services were found to be lower than that of middle and high class households. The low and very low social classes used mostly the government health services because of their poor financial status.

Madhusoodhanan V (2008) had conducted a study in Trivandrum city to examine the problems of slum dwellers and various governmental measures implemented for their rehabilitation. The study showed that both the pull and push factors were influenced for the growth of slums. The push factors are family specific and the pull factors consist of employment linked migration, political support and hope of access to better social infrastructure. There has been a phenomenal increase in the total area of slums and the number of households. The increase in the number and the size of the slums may be explained in terms of the natural growth of population and net in migration. The nature of social structure of the slums was determined caste groups and economic strata. Discrimination based on the political affiliations of the people is a peculiar feature of slum in Trivandrum. The study observed that income from employment was not reflected in the living conditions of a majority of the workers. About one third of the households did not have any household furniture and nearly one sixth of the households did not have facilities such as drinking water, electricity and toilet fittings. The study revealed that several deserving slum dwellers were denied the benefits of developmental schemes because they do not have pattayam to the land that they occupy, people who do not have pattayams are more vulnerable and marginalized than those who have benefited from governmental schemes, that is the relatively better-off sections manage to extra more benefits than those who are worse off.

Retnaraj D (2001)examined that the unprecedented growth of urban slums in Kerala in recent years consequent on the hike in the price of pucca shelter and land in urban centres. There is a heavy concentration of population in class first cities in Kerala .Due to the hike in rent of houses and prices of land urban people in Kerala was forced to live in slums. There is a positive relationship between urbanization and land prices. The major factor, which led to a spurt in land prices and real estate markets in Kerala in the 1980's and in the beginning of 1990's was inflow of enormous foreign remittances. This led to growth of slums in kerala. Drinking water facilities, latrine facilities and electric connections are inadequate among the slum dwellers in Kerala.

Many studies present slum housing problems, environmental condition and slum upgrading related policy analysis. Among the many vulnerable sections in Kerala, one of the most neglected is the population in the urban slum. Very few studies related to socio economic conditions of urban slums in Kerala. Against this background the present study concentrates a detailed analysis of the socio economic conditions of slum.

\section{Theoretical Framework of Slums}

Various theories of slums have been in existence which shows that it is the changes in urban land-use pattern and lack of housing, which lead to overcrowding and improper maintenance. According to one theory derived from a study of Gulbarga City," the slums in the city are characterized by poverty, unemployment, and minimum level of organization beyond family bad habits, rivalries and conflicts among different caste and regional groups, and low level of political participation ${ }^{4}$.To illustrate the complexity of slum formation and to attempt a theory of slum growth which correlates with a theory of city growth, it will be useful to construct a simple model. This is done in Table 1.1((Insert Table 1.1 about here)

The model sorts out from a welter of variables two which are thought to be determinants of slums. One of these is the psychological attitude toward the possibility of success in moving up through the class structure by

${ }^{4}$ Dhadave, 1979 
assimilation or acculturation to full participation in the economic and social life of the community. The other is a measure of socio-economic handicaps and barriers to such movement.

Horizontally, we distinguish slums of "hope" and slums of "despair," and vertically, escalator and non-escalator classes. The distinction between "hope" and "despair" is one which to some degree must be intuitive. By "hope" is meant that quality of psychological response by the inhabitant of the slum which indicates both his intention to "better" him-self and his estimate of the probable out-come of such an effort. "Despair" by the same token denotes either a lack of such intention or a negative estimate of the probable outcome of any attempt to change status.

An escalator class is a group of people who can be expected, barring unusual circumstances, to move up through the class structure. A non-escalator class is one which is denied in some way the privilege of escalation. The psychological distinction between "hope" and "despair" may readily be converted into a distinction between the employable and the non-employable. There may be some fuzziness about the exact location of the boundary line but its nature is clear. What is involved is some social measure of "ability" seen objectively as well as subjectively. At any moment of time, the city will have determined a minimum set of "ability" standards. For each job, for example, there may be age limits preventing those who are too old or too young from gaining employment or it may prove difficult to find employment for breadwinners whose education does not go beyond the 8th grade of grammar school ${ }^{5}$.

The crucial difference which stokes makes between slums in under developed and developed countries was that technological complexity and sophistication were so high in the developed countries that the slums there contain many more people for whom there are few channels of mobility out of the slum conditions. He observed that in developed countriesslums persist because they were index of a paradox. Rising standards of living were accompanied by rising standards of ability and competence. In the US poverty has become a term which describes the conditions of a class more and more composed of the incapable. These are people who because of society's standards of entrance into job opportunitieshad not been integrated in to full participation in the economic life of the community. How to provide for these unfortunate lots, their presence should yield a costly dividend or crime and disease, remain the problem of highly developed society.

\section{Methodology}

Kannur is the fourth urbanized districts in Kerala (65.26\%, census 2011) with more than 50 percent of its residents living in urban area. The survey was conducted in two slum areas, notified and non -notified. (Insert Figure 1. 1 here)

\section{Data sources}

In the present study, both primary and secondary data were used. The primary data were collected from 212 slum households of the Kannur Municipality through a well -structured and pre-tested questionnaire. Secondary data were collectedfrom various sources like Census Reports, NSSO Reports, Town Planning Survey Reports, and Municipality Development Report and so on.

\section{Sample design}

The survey was conducted in two slum areas, notified and non -notified. A slum was defined as "compact settlement of at least twenty households with a collection of poorly built tenements, mostly of temporary nature, crowded together usually with inadequate sanitary and drinking water facilities in Unhygienic conditions ".Based on this definition municipality identified 20slums .Out of 20,9 were notified and 11 were not notified slums.25 percent of sample selected from each slum area.The details of the sample households are given in the following table (Insert Table 1.2about here)

Out of the total household in notified area,88 sample households,including 770 population are selected from three areas,namelyN.R.city P.O Palamadam, PalakkatidaAribazar, Beach road and 124 sample household consisting 749 population from non notifiedareas,such as Erummakadi,Kilazi line, Uppalavalappu,Dhobi line in Kannur municipality.For analyzing the objectives of the study, percentage, simpleaverageshas been used.To prove the relatioship between living standard and health status, chi-squared test is applied.

The formula used to test $\mathrm{x}^{2}$ is as follows.

$\mathrm{X}^{2}=\sum[\mathrm{fo}-\mathrm{fe}]^{2} \mathrm{fe}$

$\mathrm{FO}=$ Actual value or observed frequency

$\mathrm{Fe}=$ Expected frequency.

Decision criteria of $x^{2}$ test is that, if the calculated value is less than the table value, here it accept the null hypothesis (Ho) otherwise reject it or accept the alternative hypothesis (H1).

\footnotetext{
${ }^{5}$.Charles J. Stokes, 1962
} 


\section{Analysis of data}

Socio economic conditions are very influential factors in the study of any society. General observation and empirical data indicate that slum dwellers lead a subhuman existence. In order to understand the socio economic background of slum population the charactertistics of culture of poverty as postulated by Lewis need to be highlighted ${ }^{6}$. At the social level,'culture of poverty' is characterized by lack of effective participation and integration of the poor in the mainstream institutions of the larger society ,low wages and chronic unemployment and underemployment,poor housing conditions and low level of organization.On the family level,major traits identified Lewis were absence of childhood,early initiation in to sex,free unions orconsensual marriages, Lastly the features on the level of individuals are strong feeling of marginality,helplessness, dependence and inferiority .

In the present study of slum dwellers in kannur municipality, an attempt has been made to present a sketch of socio economic conditions of these family respondents. This socio economic profile of slum dwellers presents a vivid picture of factors such as caste, religion, education, marital status of head of family, health status and living environment of the family, size of the family, type of the house, occupation and annual income of the family etc.These are provided in respect of notified as well as non notifiedslums.In the tables, the result have been presented for notified,non-notified and notified non-notified combined (ie All).Notified area defined as the area were IHSDP (Integrated Household Slum Development Programme) implemented and non- notified area,theprogramme is not implemented.The data for this study is based on household survey conducted in the month of July 2011. The target respondent was either head of the household or his or her spouse.

\section{Socio-economic profile:}

Socio economic profile of slum dwellers presents a vivid picture of factors such as caste, religion, education, health status and living environment of the family, type of the house, occupation and annual income of the family etc.The variables of caste and religion play equally important role in patterning and growth of slums .In the notified slum, Muslims (93.2\%) accounted for a major community. Hindu and Christian constitute 4.5 and 2.3 percent respectively. In non notified slum, Hindus constitute 78.2 percent; Muslim and Christian constitute 17.7 and 4.1 percent respectively. It is striking feature of the society that Muslim (93.2\%) families are inhabitants of notified slum areas. In case of these Muslims lack of education, low income, lack of technical know-how are the main reasons of setting in this slum areas.Caste are an important factor influencing the socio economic status of any society. In notified slum, Other Backward Classes like Muslim, Christian, and Yadava (95.5\%) were the largest community of slum dwellers in the study area. The OEC (Mukkuvar) constitute 4.5 percent .In non notified slum, OBC were the largest community's constitute 43.5 percent, OEC was 18.5 Percent and general (Pattar) were .8 Percent.Education status of the head is significant for analysis because education status of the head reflects in the perception of the health of the household. We observe that 58 and 36.4 percent of households were literate in notified and non notified area respectively. In the notified area, among male head of household, 45.4 percent were literate, female household literate were 13.6 percent. In non notified area, 32.4 percent of the males and 4 percent of the females were literate. It shows that Female literacy rate was very low as compared to male literacy rate and also number of literate was very low in non notified area.

The employment status is a basic indicator of economic soundness of households. Majority of the person include unskilled work like fishing, coolie, cow rearing, and construction work .It show that number of unemployed person is very high in females as compared to males. The domination of unskilled work among the marginalized communities reflects uncertainty of income on their part .The quality of life is measured directly with the help of the family income. Household income measured from Rs $0-2000$ a month in this sample. The distribution of household income in table3 shows that around 94 percent of household reported an income of less than Rs 1000 a month. The remaining 6 percent received between Rs 1000 and 2000 in notified areas. In non notified areas, around 93 percent had income less than Rs 1000, 7 percent had income between Rs 1000 and 2000.Monthly Percapita Income is an important criteria used for measuring the standard of living of the people. In this sample, majority of household (83.8 and $84 \%$ ) had a monthly percapita Income of less than Rs 150 in notified and non notified areas. These households are, without doubt, extremely poor. Another 9.1 percent $(9.6 \%$ in non notified area) of households, with percapita income in the range of Rs 150-300 can also be characterized as very low households. Around 4 percent (6\% in non notified area) of households reported a percapita Income of RS 300-750.Thus the low monthly income of the households reveals the economic depriviation among them which reflects in their living standard.( Insert Table 1.3 about here)

\footnotetext{
${ }^{6}$ Thaker RN and Dhadave MS ,1986
} 


\section{Relationship between living environment and health status:}

Living conditions have a direct impact on health.The availability of latrines is an important indicator of the sanitation. The living condition in slums are usually unhygienic and are an important factor in accelerating transmission of various water borne diseases.(insert Table 1.4 here)

Table 1.4 reveals that there is a strong relationship between living environment and health status.In order to analyse the relationship between living environment and health status,chi-square test is applied in the above data.For this purpose we use the hypothesis is that bad living environment adversely affect the health status of the people.

Ho: There is a direct relationship between living environment and health status

H1: There is no direct relationship between living environment and health status

Here the calculated value is 4.4 . The level of significance is $0.05 \%$. The table value is 9.448 and it is greater than the calculated value. Here we rejected the alternate hypothesis H1, and accept the null hypothesis Ho. it is explained by the $\mathrm{X}^{2}$ test that there is a positive relationship between living environment and health status. Here it's concluded that, living environment adversely affect the health status of the people.

Poor sanitary condition and poor quality of water lead to illness like diarrhoea and othe water borne diseases.slums are considerably disadvantaged as far as source of drinking water were concerned.Inslums,none of the household use any kind of scientific device for pathogen killing or germs filteration. Of those with access to well, 6.9 percent of households reported no illness, whereas among those with access to public tap was 9.1 percent in notified areas. In non notifiedarea ,it was 4.8 and 6.4 percent respectively. There is a direct relationship between public tap and incidence of illness(insert Table 1.5 here)

\section{Basic Amenities available in the slum}

Basic amenities available in the urban slum reveal the miserable living conditions of the slum dwellers. It measured through the availability of toilet, bathroom, drinking water facility, drainage, garbage disposal, electricity, cooking fuel etc. House constitutes the most vital aspect of the basic needs of man. Every individual needs to protect his life from thieves, flood etc.For this purpose proper house is necessary for everyone. On the basis of maternal used in walls and roofs, we classified all houses in to three categories, Pucca, Semi pucca and Kutcha .A pucca house is one, which is constructed with cement and concrete roofing. Semi pucca house is constructed with stone with cement and concrete roofing. A kutcha house is made of mud with thatched and or tin sheet roofing. In notified area, only 25 percent were pucca house. The largest houses $(68.2 \%)$ were a semi pucca house and only 6.8 percent houses were kutcha house. In non notified area, around 79 percent of houses were semi pucca and 14.6 percent of houses were kutcha and only 6.4 percent were pucca house. Available field data reveals that around 47 percent of notified household had two rooms in the house and 43 percent of non notifiedhouses had only single rooms for cooking,eating,sleeping and reading without any toilet and bathrooms. In non notified area, it was 53 and 43 percent respectively. The data reveals that very few household had three and above rooms. The most crowded household had 7 persons per room. In notified area, 59.1 percent of houses, there were 4 or more persons per room.Innon notified area, it was 21 percent.

Availability of toilet is an important indicator of the sanitation. Toilet is one of the most serious and common problems among all urban poor. In notified area, 86.4 percent of households did not have a toilet in their home. In non notified area, it was 89.4 percent. Out of the total households, 34.3 percent said that they used public toilet, while 13.6 percent used open area, only 13.7 percent their own toilet in notified areas. In non notified area, 33.9 percent used public toilets, 12.9 percent open area and 30.6 percent used their own toilets. The use of open spaces is likely to be higher in notified area as compared to non notified area (table 4).Lack of proper toilet and use of open space by these deprived communities results in the outbreak of communicable illness during winter season and this account for hike in the morbidity. Most houses had a small area partitioned in some way that was used for bathing. In notified area, 70.4 percent of the houses having bathroom. In non-notified area, it was 67.7 percent. Clean water is need for drinking and cooking. Dirty water lead to the spread of many diseases, epidemics etc.In order to avoid all these defects pure drinking water facility should be made available to the people. Almost all households in slum rely on the municipal water supply for all purposes from drinking and bathing to kitchen and laundry. The water supply in the slum area is much below the requirement of the people. Municipal tap is the major source of water for the people of that time. Two or three hours are spending every day in the quee to collect the water for daily use. Slums are considerably disadvantaged as far as source of drinking water are concerned. Table 4 reveals that 6.8 percent of household had well in notified area, another 93.2 percent of household had access to municipal water supply. In non notified area, 38.7 percent of household had well and 61.3 percent of household had access to public tap. In cases of drainage system 17.1 percent of the notified household did not have any drainage facility. In non notified area, it was 32.3 percent. They are living in the dirty condition. All household dumped garbage in the 
open, beach side and other areas.81.8 percent of households dumped garbage in the public place. In non notified area, it was 40.3 percent. Only 2.3 percent of houses were not electrified in notified area and 3.2 percent in non notified area. We found that the proportion of non electrified houses was greater in the notified area as compared to the non notified area. (insert Table 1.6 here)

\section{Saving}

Around 15.9 percent of households reported no saving in notified area .Majority of the household ( 84.1 and 74.1 respectively) had a semi formal saving scheme(kudumbasree) in notified and non notified area.9.7 percent of household had bank or post office saving account.Table reveals that very few person had a bank or post office saving.(insert Table 1.7 here)

\section{Availability of Radio and TV}

Radio and TV are the potent media to spread awareness about the incidence, spread and prevention of diseases and also the status of the environment. It is also effective in bringing about life style changes in the society. Table 1.7 reveals that slum dwellers have better access with TV than in Radio and Newspaper. In notified area none of them subscribe newspapers and very low percentage possesses radio. This is the main reason due to lack of awareness about programmes and policies of the government. (insert Table 1.8 here)

\section{Poverty line Classification}

Economic status leads to increasing the standard of living of the people. The type of ration card is an important document to prove the extent of poverty of households before the authorities. The division of ration card reveals the 9.1 percent of notified household are very poor and belongs to anthyodaya card and where as among the non notified area it was 9.6 percent . The proportion of BPL category was 68.2 and 69.4 percent notified and non notified area respectively. The figure reveals that majority of them belonged to Below Poverty Line. This shows that Poverty still a major problem in slum area. It shows that need for providing considerations for these groups accounting to their economic improvement. (Insert Figure 1.3 here)

\section{Opinions}

Opinions are important vehicle through which one could understand the existing mental attitude of people in general and groups, and community in particular. Not only the environment or public utility services but also socio economic problems such as poverty and employment are acute to urban poor. This could be a reason why urban poor lives in slums despite lack of basic amenities. To this, we identified nine potential issues pertinent to the urban poor and asked them to rank from 1-9 as per severity (i.e. priority) to solve in their family and community. The overall ranking was determined based on weight age of all respondents in each slum. . (Insert Table 1.9 here)

To sum up, the large numbers of people in slums are forced to live miserable conditions. The housing conditions of the slum dwellers are very deplorable with no latrine and bathroom. Thus, from the preceding discussion it is concluded that socio economic condition of the slum dwellers are very deplorable.

\section{Summary and Conclusion}

Slums are the product of socio-economic and cultural conditions of a particular social system inhibiting the physical, mental, moral and social development of the individuals. Kurien (1995) observed that the basic amenities related to housing such as electric lighting, toilet facilities and access to water are also at far lower standards in the fishing villages of Kerala when compared to the state as a whole.For analyzing the socio economic condition of slum dwellers, the present study is taken seven slum areas of kannur municipality.212 sample households were taken for the study.From the analysis, it is found that the socio economic conditions of the slum dwellers in the notified areas where the IHSDP (Integrated household Slum Development Programme) implemented,are better than slums in non notified area.

\section{Major findings of the present study are listed below.}

Each slum has listed some facility needs urgent attention. For instance, water supply and drainage access in the area. All most all households reported lack of drainage; Potable water and toilet facilities as critical issues .Most of the residents of slums do not constitute a skilled working class. They engage themselves as construction labour, coolies, fishing etc.These jobs are low income generating activities.

Considering the demographic particulars, it is observed that the slum household have an average family size is 6.9 percent in notified and 4.9 percent in non notifiedslum.A large household had up to 10 members in notified area. Most of the household were headed by males.In notified slum, 53 percent were headed by males and 46.9 percent by females and non notifiedslum,it is 54.1 and 45.9 percent respectively.In notified 
slum,muslim $(93.2 \%)$ is a major community and non notified area,78.2 percent of population were belonged to Hindu communities.Considering the charecteristics of the head of the household,especially in female headed household,the women were divorced or separated in a majority of cases.

The housing conditions in the slum presents a grim scenario.About 25 percent of houses are pucca and 68.2 percent were semi pucca in notified area and non notifiedarea, it is 6.4 and 79 percent respectively. The largest household had a semi puccahouse.Most of the household have only one room. The most crowded household had seven person to a room.As regard other amenities, it has been observed that 86.4 and 69.4 percent of notified and non notified household have no latrines.Thus the slum dwellrs suffer from tremandeousdepriviation of sanitation,roomspace,cooking,bathing,defecating and washing space.Regarding the electrification of the slum households, it has been observed that majority of the household had a electricity.

The rate of literacy for males and females were 82.5 percent and 67.9 percent respectively.Morbidity rate is slightly higher in non-notified area than notified area. 25.1 percent of males and 20.5 percent of females reported suffering from some illness.In this sample,majority of households $(83.8 \& 84$ percent in nontified and non notified area respectively) had a monthly percapita income of less than Rs 150 . These households are,withoutdoubt,extremelypoor.Regarding the occupation of the households,skilled worker constitute only .4 percent in the sample households.It was observed that TV sets were commonly found in slum household.In notified area ,no one was subscribng any news paper.The above facts indicates a bleak picture of the socio economic conditions of slum dwellers.

\section{Suggestions}

The following are the major Suggestions for the study

- Most of the slums identified for the study area were low lying areas and inundated during rainy seasons. Measures should be taken to raise their level in order to avoid problems of flooding and sledging in such slums.

- The open drains alongside the road should either be provided with removable covers or appropriate arrangements should be made for their regular cleaning so as to avoid accumulation of sewage.

- Local government should provide more facility of public latrines for prevention of water and land pollution.

- Local government should undertake measures to improve the physical environment of the dwelling places, proper drainage, sewerage system and adequate water supply.

- Slum clinic or mobile clinic van should be arranged for treatment of common morbities and health promotional activities.

- Local government should develop strategies to prevent the formation of new slums. These should include access to affordable land, reasonably priced materials, employment opportunities and basic infrastructures.

\section{Conclusion}

The rapid growth of population in urban centers since independence has led to the emergence and growth of urban slums in the country. The developmental activities in urban centers provide employment to the rural migrants as well as the local urban population. These low income groups, in the absence of proper shelter were settled in pockets of the slum areas characterized by overcrowding, dilapidated dwellings, lack of sanitation and civic amenities. Realizing the gravity of the situation governments have implemented a number of schemes and programmes to improve the living conditions of people living in slums. Our study has shown that in the notified area conditions of slum dwellers are better than that of non-notified area. In the non- notified area health and living conditions are continuous to be very poor and disgusting. In short multiprolonged strategy required not only to address the needs of slum dwellers for shelter but also the problems of urban poverty, unemployment, low incomes and lack of access to basic urban services.

\section{References}

[1]. Charles J. Stokes, A Theory of Slum, Land Economics ,Vol. 38, No. 3 , PP. 187-197

[2]. Das. B, (1997), Slum Dwellers in Surat City: A Socio Demographic Profile, Indian Journal of Social Work, New Delhi, Sage Publications

[3]. Gangadharan K (2005), Utilization of Health Services in Urban Kerala: A Socio Economic Study Serials publications, New Delhi

[4]. Gurumukhi K.T (2000), slum Related Policies and Programmes, shelter, Vol 3 No.3, pp 57.

[5]. HatekarNeeraj and Rode Sanjay (2003),Truth about Hunger and Disease in Mumbai, Malnourishment among slum children Economic and Political Weekly, Vol 38, No 43, PP 4604-4610..

[6]. Joshi Seema (2005),Marriage, Migration and Labour market in slum areas, Nagarlok, vol 37,No 3,PP 34-49.

[7]. KarnS.K,ShigeoShikura and Harada Hideki(2003),Living Environment and Health of Urban poor: A study in Mumbai, Economic and Political Weekly, Vol 38, No 34, PP 3575+3579-3586.

[8]. Kumar P (2001), Declining number of slums: Nature of Urban Growth, Economic and Political Weekly, Vol xlv, No 41, PP 75-77.

[9]. Madhusoodhanan,V. (2006), Rehabilitation Measures for Slum Dwellers in Thiruvananthapuram City, in Ed Nair,K.N and Gopikuttan,G, Housing in Kerala, New Delhi, Daanish Books.

[10]. Mohanty and M Swati.Slums in India, APH Publishing Corporation,New Delhi 
[11]. Mony PK, Varghese L,George A (2006),Demography, Environmental Status and Maternal health care in slums of Vellore town, south India ,Indian journal of community medicine, Vol 31,No 4,230-4233.

[12]. Nair,K.N and Gopikuttan,G (2006) in Ed Nair,K.N and Gopikuttan,G, Housing in Kerala, New Delhi, Daanish Books.

[13]. Nautiyal, (1993), Basic Education In slums Of Delhi: The Growing Menace of Urban Neglect, Journal of educational Planning and Administration, Vol 7, No 3, PP 453-473.

[14]. Naveen Kumar and Agarwal SC (2003),Patterns of consumption and Poverty in Delhi slums, Economic and Political Weekly, Vol 31, PP 5294-5300

[15]. Retnaraj D (2001), Fast Growing Cities, Spurt in Land Prices and Urban Slums: The Kerala Experience, IASSI Quaterly, Vol 20, No 2, PP 123-133.

[16]. Retnaraj, D. (1997) Patterns and Causes of Urbanization in Ed, Prakash, B.A, Kerala Economic Development :Issues and Problems, New Delhi, Sage Publications

[17]. Thaker RN and Dhadave MS (1986), A Critique of Theories on Slums in the light of studies on Indian Slums, India,Nagarlok, Vol 18,No 3,PP 44-52.

[18]. Thomas Isaac and Michael Tharakan”Kerala, towards a new agenda “, Economic and Political Weekly, Vol 30, No 03, PP1993-2004.

\section{Appendix}

Table 1.1: A Model on Slums

\begin{tabular}{|c|c|c|}
\hline Classes & Hope & Despair \\
\hline Escalator & $\mathrm{A}$ & $\mathrm{B}$ \\
\hline Non-escalator & $\mathrm{C}$ & $\mathrm{D}$ \\
\hline
\end{tabular}

Source: Charles j Stroke (1962), Land Economic

Figure 1.1

Location of slums in Kannur
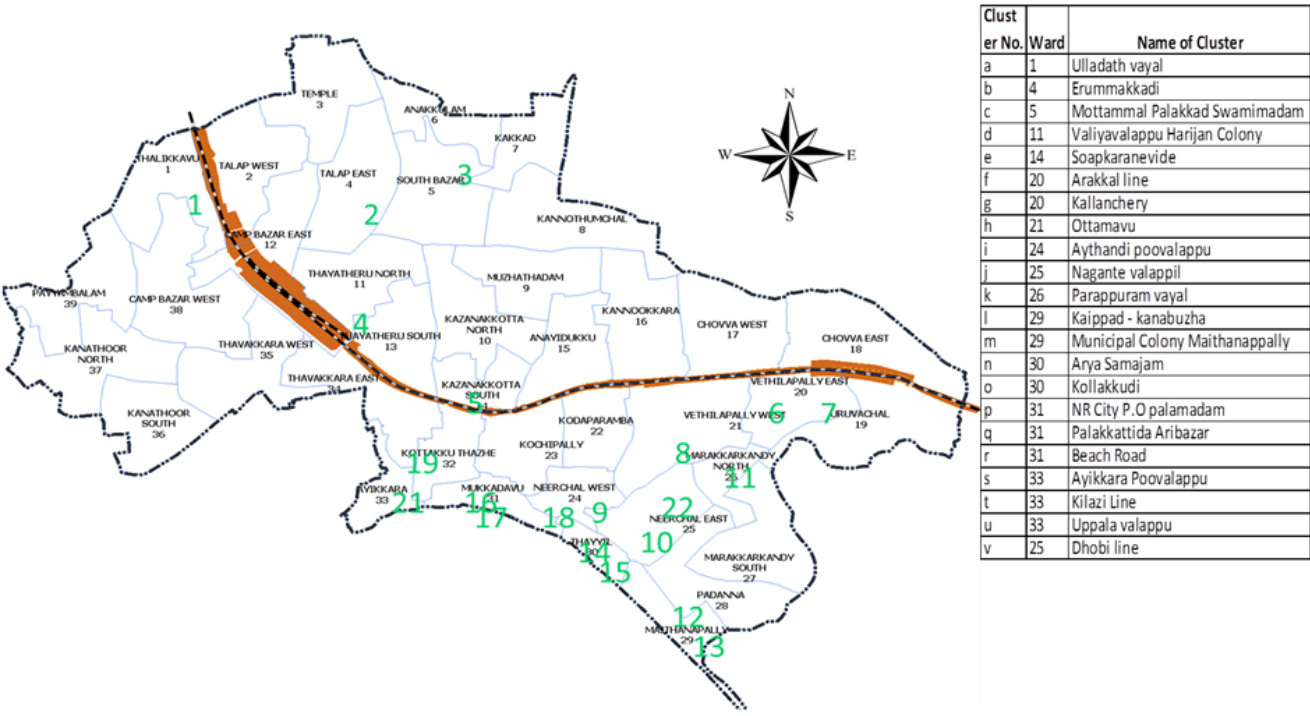

Source: Town Planning Office2011, Kannur

Table 1.2: Details of Sample Household

\begin{tabular}{|c|c|c|c|c|}
\hline Name of the slum & Ward Number & $\begin{array}{l}\text { Total number } \\
\text { of households } \\
\text { as collected } \\
\text { from Kannur } \\
\text { municipality }\end{array}$ & $\begin{array}{l}\text { Number of } \\
\text { sample } \\
\text { households }\end{array}$ & $\begin{array}{l}\text { Total } \\
\text { Population }\end{array}$ \\
\hline $\begin{array}{l}\text { Notified (i) } \\
\text { 1.N.R.city } \quad \text { P.O } \\
\text { Palamadam } \\
\text { 2.Palakkatida } \\
\text { Aribazar } \\
\text { 3.Beach road }\end{array}$ & $\begin{array}{l}31 \\
31 \\
31\end{array}$ & $\begin{array}{l}352 \\
30 \\
30 \\
30\end{array}$ & 88 & $\begin{array}{l}770 \\
156 \\
369 \\
245\end{array}$ \\
\hline $\begin{array}{l}\text { Non Notified(ii) } \\
\text { Erummakadi } \\
\text { Kilaziline } \\
\text { Uppalavalppu } \\
\text { Dhobi line }\end{array}$ & $\begin{array}{l}4 \\
33 \\
33 \\
25\end{array}$ & $\begin{array}{l}490 \\
45 \\
25 \\
50 \\
23\end{array}$ & 124 & $\begin{array}{l}749 \\
252 \\
255 \\
187 \\
55\end{array}$ \\
\hline
\end{tabular}


Socioeconomic conditions of urban slum dwellers in kannur municipality

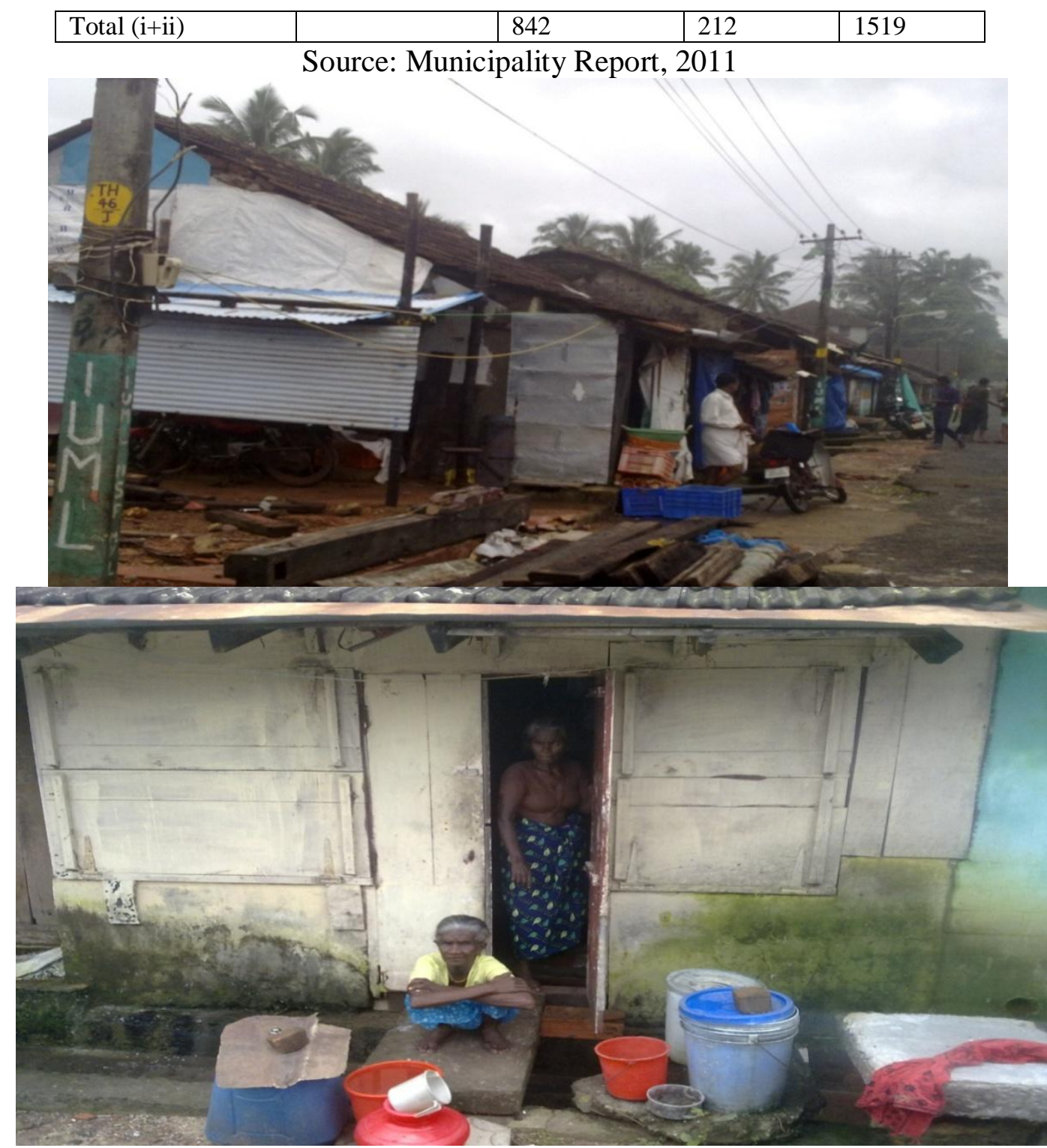

Table 1.3: Socio Economic Characteristics of Sample Households

\begin{tabular}{|c|c|c|c|}
\hline & Notified & Non - Notified & All \\
\hline Religion & & & \\
\hline Hindu & 4.5 & 78.2 & 47.6 \\
\hline Muslim & 93.2 & 17.7 & 49.1 \\
\hline Christian & 2.3 & 4.1 & 3.3 \\
\hline Caste & & & \\
\hline SC & & 18.5 & 10.8 \\
\hline OBC & 95.5 & 43.5 & 65.1 \\
\hline OEC & 4.5 & 37.2 & 23.6 \\
\hline General & & 0.8 & 0.5 \\
\hline Education & & & \\
\hline Literate & 58 & 36.4 & 45.8 \\
\hline Illiterate & 42 & 63.6 & 54.2 \\
\hline Occupation & & & \\
\hline Skilled worker & & 0.4 & \\
\hline Unskilled worker & 68.4 & 63.6 & 43.36 \\
\hline Monthly PCI & & & \\
\hline Less than 150 & 83.8 & 85 & 81.3 \\
\hline
\end{tabular}


Source: Field survey-2011

Table1.4 Incidence of illness and availability of toilet

\begin{tabular}{|c|l|l|l|l|l|l|}
\hline & \multicolumn{2}{|l|}{ Notified area } & Non notified area & All \\
\hline $\begin{array}{l}\text { Availability } \\
\text { toilet }\end{array}$ & $\begin{array}{l}\text { No } \\
\text { Illness }\end{array}$ & $\begin{array}{l}\text { Some } \\
\text { illness }\end{array}$ & $\begin{array}{l}\text { No } \\
\text { Illness }\end{array}$ & $\begin{array}{l}\text { Some } \\
\text { illness }\end{array}$ & $\begin{array}{l}\text { No } \\
\text { Illness }\end{array}$ & $\begin{array}{l}\text { Some } \\
\text { illness }\end{array}$ \\
\hline Yes & $10(11.5)$ & $2(2.2)$ & $12(9.7)$ & $24(19.4)$ & $22(10.4)$ & $26(12.3)$ \\
\hline No & $(2(2.2)$ & $74(84.1)$ & $2(1.6)$ & $86(69.3)$ & $4(1.9)$ & $160(75.4)$ \\
\hline Chi-Square & 5.4 & 6.4 & 4.4 & \\
\hline
\end{tabular}

Source: Field survey2011, Figures in parenthesis indicate percentage

Table: 1.5

Distribution of households by incidence of illness and sources of drinking water

\begin{tabular}{|l|l|l|l|l|l|l|}
\hline $\begin{array}{l}\text { Sources of } \\
\text { drinking water }\end{array}$ & \multicolumn{2}{l|}{$\begin{array}{l}\text { Notified area } \\
\text { incidence of illness }\end{array}$} & \multicolumn{2}{l|}{$\begin{array}{l}\text { Non notified area incidence } \\
\text { of illness }\end{array}$} & \multicolumn{2}{l|}{ All } \\
\hline & No illness & Some illness & No illness & Some illness & $\begin{array}{l}\text { No } \\
\text { illness }\end{array}$ & $\begin{array}{l}\text { Some } \\
\text { illness }\end{array}$ \\
\hline Public tap & $8(9.1)$ & $70(879.5)$ & $8(6.4)$ & $68(54.8)$ & $16(7.5)$ & $138(65.1)$ \\
\hline Private well & $6(6.9)$ & $4(4.5)$ & $6(4.8)$ & $42(34)$ & $12(5.7)$ & $46(21.7)$ \\
\hline
\end{tabular}

Source: Field survey2011, Figures in parenthesis indicate percentage

Table: 1.6 Housing, Drinking Water and Sanitary Conditions in the Study Area

\begin{tabular}{|c|c|c|c|}
\hline & Notified & Non - Notified & All \\
\hline \multicolumn{4}{|l|}{ Housing } \\
\hline Pucca & 25 & 6.4 & 14.1 \\
\hline Semi Pucca & 68.2 & 79 & 74.6 \\
\hline Kutcha & 6.8 & 14.6 & 11.3 \\
\hline $\begin{array}{ll}\text { Single } & \text { Roomed } \\
\text { Households } & \end{array}$ & 43.2 & 47.7 & 9.1 \\
\hline \multicolumn{4}{|l|}{ Toilet } \\
\hline Private toilet & 13.7 & 30.6 & 23.6 \\
\hline Public toilet & 34.3 & 42 & 34 \\
\hline Open area & 23.6 & 16 & 13.2 \\
\hline Both & 52.4 & 22.4 & 29.2 \\
\hline \multicolumn{4}{|l|}{ Bathing Area in House } \\
\hline Yes & 70.4 & 67.7 & 68.9 \\
\hline No & 29.6 & 32.3 & 31.1 \\
\hline \multicolumn{4}{|c|}{ Sources of Drinking Water } \\
\hline Private Well & 6.8 & 38.7 & 41.5 \\
\hline Public tap & 88.6 & 61.3 & 74.5 \\
\hline \multicolumn{4}{|l|}{ Drainage Facility } \\
\hline No Drainage & 17.1 & 32.3 & 25.9 \\
\hline \multicolumn{4}{|l|}{ Garbage Facility } \\
\hline Public Space & 82 & 40.3 & 57.5 \\
\hline Burning & 18 & 59.7 & 42.5 \\
\hline \multicolumn{4}{|l|}{ Availability of Electricity } \\
\hline Yes & 97.7 & 96.8 & 97.2 \\
\hline No & 2.3 & 3.2 & 2.8 \\
\hline
\end{tabular}

Source: Field survey2011

Table: 1.7 Distribution of households by mode of saving 
Socioeconomic conditions of urban slum dwellers in kannur municipality

\begin{tabular}{|c|c|c|c|}
\hline Mode of saving & $\begin{array}{c}\text { Number of household, } \\
\text { notified area }\end{array}$ & $\begin{array}{c}\text { Number of household, } \\
\text { non notified area }\end{array}$ & All \\
\hline $\begin{array}{c}\text { Bank or post office } \\
\begin{array}{c}\text { Semi formal saving } \\
\text { scheme }\end{array}\end{array}$ & $74(84.1)$ & $12(9.7)$ & $12(5.7)$ \\
\hline None & $14(15.9)$ & $92(74.1)$ & $166(78.3)$ \\
\hline Total & $88(100)$ & $20(16.2)$ & $34(16)$ \\
\hline
\end{tabular}

Source:Field Survey 2011, Figures in parenthesis indicate percentage

Table 1.8 Distribution (\%) of household using type of Media

\begin{tabular}{|c|c|c|c|c|c|c|c|c|c|}
\hline \multicolumn{3}{|c|}{ TV } & \multicolumn{3}{c|}{ Radio } & \multicolumn{3}{c|}{ Newspaper } \\
\hline Area & Yes & No & Total & Yes & No & Total & Yes & No & Total \\
\hline Notified & 63.6 & 36.4 & 100 & 21.6 & 78.4 & 100 & - & 88 & 100 \\
\hline $\begin{array}{c}\text { Non } \\
\text { notified }\end{array}$ & 62.9 & 37.1 & 100 & 17.7 & 82.3 & 100 & 19.4 & 80.6 & 100 \\
\hline All & 63.2 & 36.8 & 100 & 19.3 & 80.7 & 100 & 11.3 & 88.7 & 100 \\
\hline
\end{tabular}

\section{Figure 1.3 Distribution of Household by Type Of Ration Card}

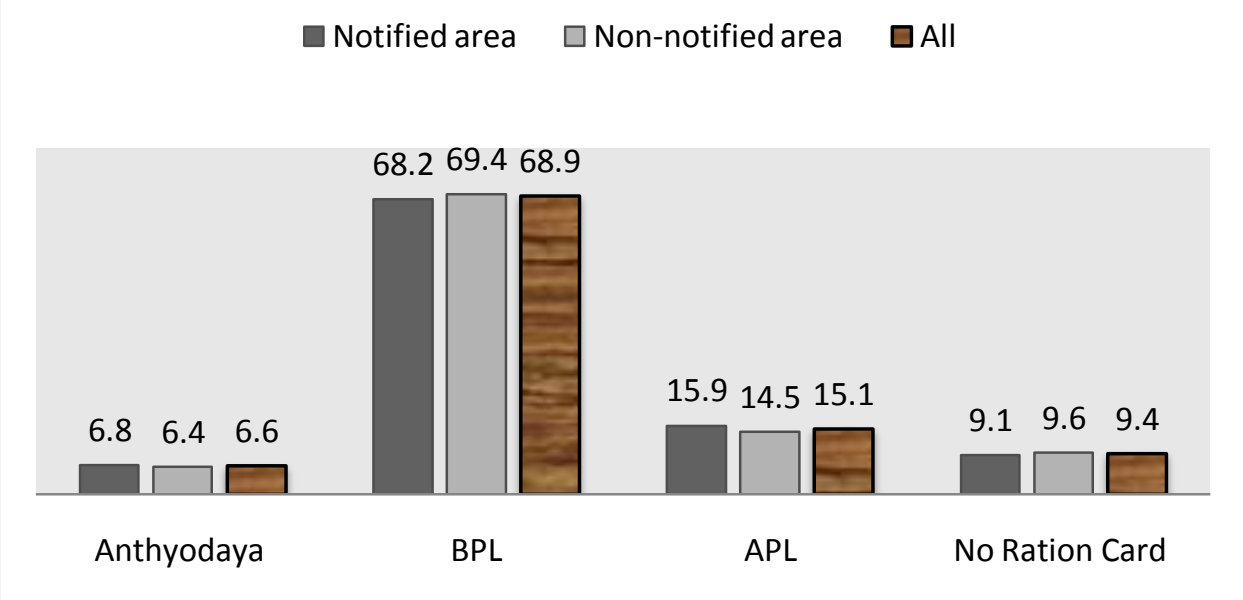

Table 1.9 Distribution of household to the rank order of most urgent need

\begin{tabular}{|c|c|c|c|}
\hline Issues & $\begin{array}{c}\text { Rank order- } \\
\text { Notified Area }\end{array}$ & $\begin{array}{c}\text { Rank order-Non } \\
\text { notified Area }\end{array}$ & \\
\hline Housing condition & 1 & 3 & 1 \\
\hline Drinking water & 2 & 2 & 2 \\
\hline
\end{tabular}


Socioeconomic conditions of urban slum dwellers in kannur municipality

\begin{tabular}{|c|c|c|c|}
\hline Toilet & 3 & 1 & 3 \\
\hline Poverty(food) & 4 & 4 & 4 \\
\hline Unemployment & 5 & 6 & 5 \\
\hline Sewerage and drainage & 6 & 5 & 6 \\
\hline Social safety & 7 & 9 & 8 \\
\hline Land ownership & 8 & 7 & 9 \\
\hline Healthcare facilities & 9 & 8 & \\
\hline
\end{tabular}

Source: Field Survey 2011 